\title{
Is cardiac surgery training really hazardous?
}

\author{
M El Saegh ${ }^{1 *}, H$ El Saegh ${ }^{2}, T$ Theologou', P Yiu ${ }^{3}$ \\ From 23rd World Congress of the World Society of Cardio-Thoracic Surgeons \\ Split, Croatia. 12-15 September 2013
}

\section{Background}

Most of the times patients, and sometimes surgeons (even trainees) may feel that cardiac surgery training isn't very safe, and may affect the outcome.

\section{Methods}

1 year retrospective post-operative analysis of 520 patients who underwent isolated CABG surgery based on morbidity and mortality. The patients were divided into: patients operated by consultants (C), 444 patients and patients operated upon by registrars under supervision (F); 76 patients.

\section{Results}

Our results showed highly significant difference in the registrars group compared to consultants for cumulative cardiopulmonary bypass time, and aortic cross clamp time; $\mathrm{p}<0.01$. While there was significant difference concerning post operative chest infection, $\mathrm{p}<0.05$ in the registrars group. There was no statistically significant difference in logistic euro score, in-hospital mortality, incidence of post operative infection, post operative renal impairment, post operative arrhythmias, ICU readmission, post operative stay, reopening or the need for inotropes.

\section{Conclusion}

Cardiac surgery training isn't really a compromise on outcome of patients undergoing CABG.

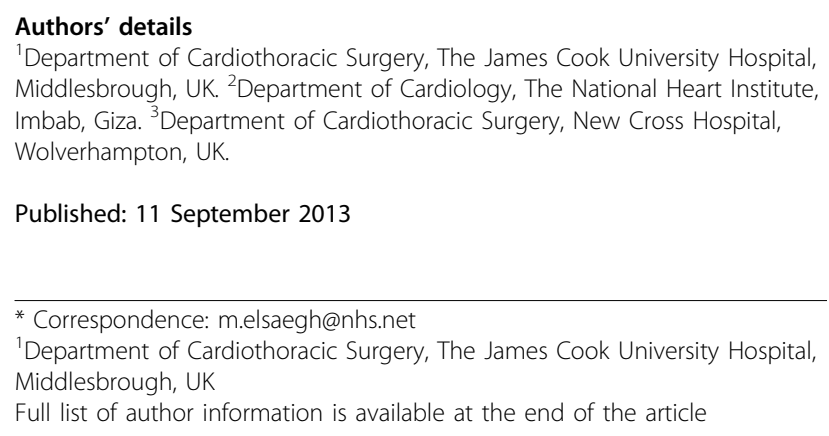

Published: 11 September 2013

\footnotetext{
* Correspondence: m.elsaegh@nhs.net

'Department of Cardiothoracic Surgery, The James Cook University Hospital, Middlesbrough, UK

Full list of author information is available at the end of the article
}

doi:10.1186/1749-8090-8-S1-094

Cite this article as: El Saegh et al:: Is cardiac surgery training really

hazardous? Journal of Cardiothoracic Surgery 2013 8(Suppl 1):094.
Submit your next manuscript to BioMed Central and take full advantage of:

- Convenient online submission

- Thorough peer review

- No space constraints or color figure charges

- Immediate publication on acceptance

- Inclusion in PubMed, CAS, Scopus and Google Scholar

- Research which is freely available for redistribution

Submit your manuscript at www.biomedcentral.com/submit

\section{() Biomed Central}

\section{Ciomed Central}

